\section{Holland and the War}

THIS aspect is obviously of interest in relation to the question of European order on which Prof. G. N. Clark's pamphlet (No. 49, "Holland and the War") has an important bearing. Prof. Clark gives a picture of the economic position of Holland, her social structure and her constitution, and against this background describes her foreign policy in recent years and the circumstances under which she entered the War with her powerful material resources in the East Indies. He describes briefly the effects of the German occupation and Holland's aims in the Wara just and stable international order-and emphasizes the value of the freedom of the Netherlands to the civilization of the world. The preservation of that freedom, when restored, depends on the collective strength and wisdom of the friends of justice.

\section{Carnegie United Kingdom Trust}

THe twenty-seventh annual report of the Carnegie United Kingdom Trust (Dunfermline: The Trust) covers the year 1940 and emphasizes the aim of its war-time policy to continue so far as possible to foster pioneer experimental work which may be expected to have an enduring effect on the social structure of the country. It also aims at safeguarding its own past work where this has proved to be of value by assisting earlier beneficiaries to maintain their services and, if necessary, extend them to meet special needs arising from the War. The year 1940 was the last year of a quinquennium, and the report briefly reviews the allocations made during that period. The largest single allocation was one of a $£ 150,000$ for land settlement schemes to be undertaken in England and Wales by the Land Settlement Association. The policy of this Association had to be completely re-orientated at the outbreak of war. At September 30, 1940, there were 1,054 holders on fulltime estates, and the land has been brought under cultivation for production of corn, potatoes and other crops under schemes agreed with the county war agricultural committees. Individual grants to the National Council of Social Service have been rounded into a single block grant of $£ 5,000$ for 1940 to cover all those of the Council's activities in which the Trust is interested.

In the field of adult education, the main allocations during the period have been for the adaptation and equipment of Lord Lothian's gift of New Battle Abbey as a residential college for adult education and for two special inquiries into the problems of young people between the ages of eighteen and twenty-five. The preliminary area reports in the Age Group Enquiry reached an advanced stage of completion by the autumn of 1939 , and the report covering the Cardiff district is being published independently under the auspices of the South Wales Council of Social Service and the Welsh University Press Board. The continued development of the Regional Library Bureaux presents the most interesting feature of library history of the last five years, and reference is made in the report to the assistance given to these Bureaux as well as to the National Central Library. Bulk allocations approved for 1941 include $£ 8,000$ to central libraries, $£ 5,000$ to the National Council of Social Service, $£ 20,000$ for youth services and $£ 3,500$ for land settlements. An immediate grant of $£ 2,700$ has been promised to the National Council of Girls Clubs to establish a bursary fund for training potential youth leaders and the salaries and expenses of supervisors of training. A grant of $£ 2,000$ for experiments in Oxfordshire on the establishment of a number of youth service camps has also been promised.

\section{Acoustics of Argentine Chamber of Deputies}

A DEscription is given by S. D. Wilburn and S. C. Tenac in Electrical Communication (19, No. 3 ; 1941) of the system of microphones and loud-speakers designed by the Union Telefonica for the Argentine Chamber of Deputies in Buenos Aires and installed late in 1939. Investigation showed that the pronounced acoustical difficulties of the Chamber were due solely to the absence of reverberation. Structural alterations were not feasible and a system including a microphone for each individual had to be devised. The new system was first used officially at the opening session in 1940, and has given great satisfaction. It comprises 193 microphones and four loud-speakers in the Chamber. It has two independent channels of transmission : one with five microphones consisting of one each for the president of the Chamber of Deputies and the two secretaries and two on the ministers' table; the other channel is equipped for 188 individual-microphones for the deputies. The Chamber is completely surrounded by two walls with three-metre corridors between them at various heights. The four loud-speakers are located in the first gallery. A simple schematic circuit diagram of the transmission, switching and power circuits is given. The electric power consumption of the system is only $1 \cdot 1$ kilowatts.

\section{Sylviculture of some Tropical Trees}

To the forester versed in tropical forestry and who has had the opportunity of discussing sylvicultural problems with the mixed gathering found. at an international forestry congress, perhaps the most interesting section in the Malayan Forester (January, 1941) is that in which observations are made on the sylvicultural characteristics of some of the important timber species. The coppicing powers of dipterocarp regeneration show that Dryobalanops oblongifolia, Dipterocarpus Kerrii and the balan and the white meranti groups of Shorea coppice fairly freely, while the red merantis and merawan (Hopea spp.) do not: There appears also to be some indication that ability to coppice and hardiness go together ; for example, Shorea ovalis is one of the few red merantis to show some ability to coppice, whilst it has also shown itself more tolerant of transplanting than most of its group. How valuable are such practical notes is known only to those tropical foresters scattered about in India, Africa and elsewhere, who are dealing with similar problems with 
valuable timber trees of the same genera or families, the knowledge of the secrets of the regeneration of which is absolutely vital to the work of replacing the often primeval stands he is dealing with.

It was the Indian forest officer (should we now say the Burman forest officer ?) who first studied the effects of firing the forest floor in the interests of obtaining successful regeneration of a valuable timber species. In Malaya preliminary investigations show that burning of the undergrowth is a prerequisite for the regeneration of Melaleuca leucadendron. An intentionally burnt area and one accidentally fired were equally successful in a covering of germinating seedlings; whilst an adjoining unburnt area appears to be as devoid of regeneration as ever. These practical observations in the forest (they cannot be undertaken in a research laboratory) are of the very greatest importance and of absorbing interest. In the case of the tropical forest they had their first beginnings in India, where a considerable amount of information had been collected by the end of last century. The present century has witnessed in some cases the results being put to a practical use.

\section{Antarctic and Sub-Antarctic Starfishes}

THe Asteroidea of the Sub-Antarctic and the Antarctic and a few from South Africa collected by the Discovery, Discovery $I I$ and the William Scoresby have been described by W. K. Fisher (Discovery Repts., 20 ; 1940). Seventeen new species and three new forms of previously described species are described. The author gives a critical list of all the valid species from the antarctic and sub-antarctic, which number 114. He himself deals with 113 different forms, not all separate species and not all from the main region, and from the number and wide range of specimens in some of them he is able to add considerably to our knowledge of these animals. The additional information thus gained has enabled him to revise certain groups. Thus the memoir is not merely a record of species obtained but also a noteworthy contribution to our understanding of the asteroids in southern latitudes. Perhaps the most interesting species is Odinella nutrix, which is the only known member of the Brisingidæ to possess a marsupium, and this is entirely different from that in any other group of starfish possessing brood chambers. The work is illustrated by twelve photographic plates and eighteen plates of figures.

\section{Earthquake in Japan}

DURING the night of July 16-17 a strong earthquake shook the northern part of the Nagano Prefecture, some 140 miles north-west of Tokyo. It is not yet known whether there were any casualties or not, but more than thirty houses collapsed and the railway between Nagano and Niigata Prefectures was interrupted for a short while. Japan is well known at present to be in a seismically active zone for earthquakes of all focal depths. Tremors, minor shocks and even strong earthquakes as in the case cited above are moderately frequent and very large earthquakes are by no means uncommon as, for example, the Kwanto earthquake of September 1, 1923, which nearly destroyed Tokyo and Yokohama, causing tremendous loss of property and the deaths of 250,000 people, the Tango earthquake of March 7, 1927, and the Idu earthquake of November 26, 1930.

\section{Earthquakes Registered in Switzerland during 1939}

THE complete bulletin of the Swiss Seismological Stations at Zurich, Chur, Neuchâtel, Basle and Sion for 1939, compiled by Dr. E. Wanner, has just been received. It contains, besides details of equipment, three tables and six maps. The first table and the maps concern earthquakes with epicentres in Switzerland, twenty-one of which were felt by people during 1939. The greatest intensity reached was five on the Rossi-Forel scale, this being on seven occasions : at Brig-Visp on May 18; at Martigny on August 23; at Unter-Engadin on September 26; at Aargau on November 17; at Sion Lokalstoh on November 20 ; at Oberes Baselbiet on December 5 and at Innerferrera on December 7 . The second table contains a list of the details of ninety-one near earthquakes, whilst Table III contains a list with details of 178 distant earthquakes registered by the Swiss observa. tories during the year.

\section{Max Jaffé (I84I-I9II)}

Prof. Max Jaffer, an eminent German biochemist and pathologist, was born at Grünberg in Silesia on July 25, 1841. He received his medical education in Berlin, where he qualified in 1862. While still a student he took a keen interest in chemical investigations and worked in the Pathological Laboratory under the direction of W. Kühne. During 18651872 he was an assistant in the medical clinic at Königsberg under Leyden, with whom he published a work on putrid sputum which led to the discovery of the spirilla and leptothrix characteristic of putrid processes in the lungs. In 1872 he was appointed extraordinary professor and in 1880 full professor of pharmacology and medical chemistry in the Königsberg faculty. His principal work consisted in the discovery of urobilin and urobilinogen in the urine and their origin in the bile, his studies of indican and creatinin, with the tests with which his name is associated, and his investigations in urocaninic acid in the urine of dogs and of ornithin in the excrement of birds. Jaffé had an extensive consultant practice and enjoyed a high reputation as a teacher. He died on October 26, 1911.

\section{Armauer Hansen (I84I-I9I2)}

Dr. Gerhard Hendrik Armauer Hansen, the celebrated Norwegian leprologist, was born at Bergen on July 29, 1841. He received his medical education at Christiania and qualified in 1866. Two years later he was appointed assistant physician to the leprosy home at Bergen under the direction of Dr. D. C. Danielssen, the founder of the scientific study of leprosy. In 1874 he read a paper before the Medical Society of Christiania, which was published in a 